\title{
Wilson's disease or chronic copper poisoning?
}

\author{
JOHN WALKER-SMITH^ and JEANETTE BLOMFIELD \\ From the Department of Gastroenterology and the Children's Medical Research Foundation, \\ Royal Alexandra Hospital for Children, Camperdown, N.S.W., Australia
}

Walker-Smith, J. A., and Blomfield, J. (1973). Archives of Disease in Childhood, 48, 476. Wilson's disease or chronic copper poisoning? The case history is given of a child who presented at 14 months with ascites and was found to have severe micronodular cirrhosis with biochemical evidence of Wilson's disease, but in view of the severity of the pathology and early age of presentation, the possibility of chronic copper poisoning was investigated. It was found that the child's drinking water was obtained from a bore via new copper pipes. The bore water had a $p \mathrm{H}$ of $\mathbf{4} \cdot \mathbf{4}$ and after passage through copper pipes had a very high copper level of $675 \mu \mathrm{g} / 100 \mathrm{ml}$. He subsequently died from liver failure and at necropsy very high copper levels were found in his liver. The final diagnosis remains uncertain.

Disorders of copper metabolism are uncommon in childhood, but disease states are recognized where clinical manifestations are attributed to the toxic effect of copper, e.g. Wilson's disease (Scheinberg and Sternlieb, 1965; Walshe, 1967), and also to copper deficiency, e.g. Menkes' kinky hair disease (Danks et al., 1972). While acute copper poisoning is well recognized (Chuttani et al., 1965; Nicholas, 1968), the existence of chronic copper poisoning as a clinical syndrome in humans is uncertain, though such a disorder has frequently been described in sheep (Todd, Gracey, and Thompson, 1962).

The purpose of this paper is to report the case history of a child who died from the toxic effects of excess copper, but whether he died from Wilson's disease or chronic copper poisoning is not certain.

\section{Methods}

Plasma and liver copper estimations were measured by atomic absorption spectrophotc metry (Blomfield and MacMahon: 1969; Blomfield, Dixon, and McCredie, 1971).

\section{Case history}

A boy presented at the age of 14 months, with a history of 3 weeks' progressive abdominal swelling and, as it was considered he might have an abdominal catastrophe, he had had a laparotomy which revealed gross ascites and a small cirrhotic liver. $\mathrm{He}$ was admitted to the Royal Alexandra Hospital for Children 1 day

Received 2 October 1972.

^Present address : St. Bartholomew's Hospital, London E.C.1. after operation. On examination ascites was present, but otherwise no abnormality was found and there were no Kayser-Fleischer rings.

On investigation, serum bilirubin was $1.9 \mathrm{mg} / 100 \mathrm{ml}$, SGOT $340 \mathrm{mU} / \mathrm{ml}$ (normal 5-19 mU/ml), SGPT 135 $\mathrm{mU} / \mathrm{ml}$ (normal 3-19 $\mathrm{mU} / \mathrm{ml}$ ), serum alkaline phosphatase $180 \mathrm{mU} / \mathrm{ml}$, total protein $3.7 \mathrm{~g} / 100 \mathrm{ml}$, albumin $2 \cdot 1 \mathrm{~g} / 100 \mathrm{ml}$, prothrombin index $41 \%$, Hb $10 \cdot 6 \mathrm{~g} / 100$ $\mathrm{ml}$, with a film characteristic of liver disease. There was a generalized aminoaciduria, but serum amino acid levels were ncrmal.

Liver biopsy revealed a severe micronodular cirrhosis with some evidence of continuing parenchymal destruction, but no regeneration. Cytoplasmic hyaline changes were seen in some parenchymal cells. Staining with rubeanic acid indicated marked increased copper in the liver nodules. Plasma copper estimations (Table I) revealed a raised free copper level and a low caeruloplasmin level, and he had a markedly raised urinary copper level (Table II).

These results suggested that this boy had Wilson's disease, though it is most unusual for this condition to present at such an early age, with such severe pathology, and so the possibility of chronic copper poisoning was investigated.

The child lived on a dairy farm and he, his parents,

TABLE I

Plasma copper levels in patient

\begin{tabular}{l|c|c}
\hline & Patient & Normal range \\
\cline { 2 - 3 } & $\begin{array}{lc}\text { Plasma total copper }(\mu \mathrm{g} / 100 \mathrm{ml}) \\
\text { Plasma free copper }(\mu \mathrm{g} / 100 \mathrm{ml})\end{array}$ & $\begin{array}{c}(75-165) \\
(5-15)\end{array}$ \\
Caeruloplasmin $(\mu \mathrm{g} / 100 \mathrm{ml})$ & 15 & $(20-52)$ \\
& & \\
\hline
\end{tabular}

^Estimated from total copper minus free copper. 
TABLE II

Urinary copper levels

\begin{tabular}{|c|c|c|c|c|c|c|}
\hline & \multicolumn{2}{|c|}{ Before penicillamine } & \multicolumn{4}{|c|}{ After penicillamine } \\
\hline & $\mu \mathrm{g} / 100 \mathrm{ml}$ & $\mu \mathrm{g} / 24 \mathrm{hr}$ & \multicolumn{2}{|c|}{ Day 1} & \multicolumn{2}{|c|}{ Day 2} \\
\hline $\begin{array}{l}\text { Patient } \\
\text { Father } \\
\text { Mother } \\
\text { Sib } \\
\text { Normal range } \\
\text { Heterozygotes for Wilson's disease* }\end{array}$ & $\begin{array}{r}122 \\
3 \cdot 7 \\
3 \cdot 0 \\
6 \cdot 8\end{array}$ & $\begin{array}{l}927 \\
46 \\
32 \\
20 \\
6-57 \\
19-120\end{array}$ & $\begin{array}{l}54 \\
47 \\
52\end{array}$ & $\begin{array}{l}765 \\
1110 \\
285 \\
270-1160 \\
620-1530\end{array}$ & $\begin{array}{r}68 \\
100 \\
78\end{array}$ & $\begin{array}{r}1050 \\
1365 \\
335\end{array}$ \\
\hline
\end{tabular}

$\star$ Tu and Blackwell (1967).

and one 4-year-old sib drank bore water delivered to the farm house via polyethylene pipes. The home had copper plumbing. He was fed on cow's milk diluted with bore water, and vegetables, etc. were cooked in it. He was not breast fed and tinned foods were not used. The family had moved to the farm when the child's mother was 4 months' pregnant. The child's drinking water was found to contain high levels of copper (Table III). 24-hour urinary copper levels (Table II) were

TABLE III

Drinking water $\mathrm{pH}$ and copper content

\begin{tabular}{l|c|c}
\hline & $p \mathrm{H}$ & $\begin{array}{c}\text { Copper } \\
(\mu \mathrm{g} / 100 \mathrm{ml})\end{array}$ \\
\hline $\begin{array}{l}\text { Cold water from bore when } \\
\text { first turned on }\end{array}$ & $4 \cdot 8$ & 675 \\
$\begin{array}{l}\text { Cold water from bore after } \\
\text { running for 5 minutes }\end{array}$ & $3 \cdot 8$ & 30 \\
$\begin{array}{l}\text { Hot water from bore when } \\
\text { first turned on }\end{array}$ & $4 \cdot 8$ & 970 \\
$\begin{array}{l}\text { Hot water from bore after } \\
\text { running for 5 minutes }\end{array}$ & $4 \cdot 8$ & 690 \\
$\begin{array}{l}\text { Direct from bore } \\
\text { Sydney water at the Royal } \\
\text { Alexandra Hospital for } \\
\text { Children }\end{array}$ & $4 \cdot 4$ & 16 \\
\hline
\end{tabular}

normal in each parent and his sib, as were plasma copper values and serum transaminase levels (Table IV).

The urinary copper excretion for 48 hours after oral penicillamine was measured in the parents and sib, but not in the child, as the levels were grossly raised without penicillamine. The parents were given $1 \mathrm{~g}$ penicillamine per 24 hours for 2 days and the sib, who weighed $17 \mathrm{~kg}$, was given $250 \mathrm{mg}$ for 2 days. Except for the mother's second 24-hour level, which was raised, the urinary copper values fell inside the upper range for control adults, but these values also are within the range found in heterozygotes for Wilson's disease (Tu and Blackwell, 1967).

Although the child was treated with penicillamine, he became jaundiced and died 6 weeks after presentation. At necropsy, liver copper levels (Table V) were substantially raised and higher than levels found in two children with Wilson's disease previously seen at the Royal Alexandra Hospital for Children, and higher than levels reported by Cumings (1968), but brain copper levels tended to be lower than in other cases of Wilson's disease. Kidney and heart levels were high (Table V), but both these organs were histologically normal, yet staining of the kidney with rubeanic acid showed increased copper whereas none was shown in the myocardium.

\section{Discussion}

Copper is chiefly excreted in the bile and excess copper is often found in the liver in cirrhosis, biliary atresia, and neonatal hepatitis as well as in Wilson's disease. The evidence in favour of the diagnosis of Wilson's disease in this boy was a low plasma caeruloplasmin level, though his total plasma protein level was low (Walshe and Briggs, 1962), high plasma free copper, raised urinary copper output, and the histological picture. However, his drinking water contained raised levels of copper and the possibility of chronic copper

\section{TABLE IV}

Blood levels in parents and sib

\begin{tabular}{l|c|c|c|c|c}
\hline & $\begin{array}{c}\text { Plasma total } \\
\text { copper }(\mu \mathrm{g} / 100 \mathrm{ml})\end{array}$ & $\begin{array}{c}\text { Plasma free } \\
\text { copper }(\mu \mathrm{g} / 100 \mathrm{ml})\end{array}$ & $\begin{array}{c}\text { Caeruloplasmin } \\
(\mathrm{mg} / 100 \mathrm{ml})\end{array}$ & $\begin{array}{c}\text { SGOT } \\
(\mathrm{mU} / 100 \mathrm{ml})\end{array}$ & $\begin{array}{c}\text { SGPT } \\
(\mathrm{mU} / 100 \mathrm{ml})\end{array}$ \\
\hline Father & 114 & 13 & 32 & 14 & 11 \\
Mother & 152 & 11 & 44 & 4 \\
Sib & 152 & 7 & 45 & 20 & 4 \\
\hline
\end{tabular}


TABLE V

Necropsy studies. Copper in tissues of patient (mg/100 $\mathrm{g}$ dry tissue) and of 4 cases of Wilson's disease

\begin{tabular}{|c|c|c|c|c|c|c|}
\hline & Patient & Normal & Case $1^{\star}$ & Case 2* & Case $3 t$ & Case $4 t$ \\
\hline $\begin{array}{l}\text { Age at death } \\
\text { Liver } \\
\quad \text { Left lobe } \\
\text { Right lobe } \\
\text { Kidney } \\
\text { Heart } \\
\text { Cerebral white matter } \\
\text { Cerebral cortex }\end{array}$ & $\begin{array}{c}16 \text { mth } \\
336 \cdot 0 \\
325 \cdot 0 \\
64 \cdot 0 \\
171 \cdot 0 \\
5 \cdot 3 \\
12 \cdot 6\end{array}$ & $\begin{array}{l}2 \cdot 76 \pm 1 \cdot 7 \\
2 \cdot 02 \pm 0 \cdot 6 \\
3 \cdot 01 \pm 1 \cdot 7\end{array}$ & - & $\begin{array}{r}- \\
147 \cdot 0 \\
136 \cdot 0 \\
2 \cdot 9 \\
10 \cdot 7\end{array}$ & $\begin{array}{r}11 \mathrm{yr} \\
82 \cdot 5 \\
3 \cdot 0 \\
5 \cdot 9 \\
19 \cdot 9\end{array}$ & $\begin{array}{r}11 \mathrm{yr} \\
149 \cdot 5 \\
176 \cdot 4 \\
24 \cdot 7 \\
1 \cdot 9 \\
8 \cdot 9\end{array}$ \\
\hline
\end{tabular}

*Cumings (1968).

†J. Blomfield (unpublished data).

poisoning has to be considered. Cirrhosis has been reported in sheep dying from chronic copper poisoning (Pearson, 1956). There is, however, only 1 report in the literature which claims to describe a child with chronic copper poisoning (Salmon and Wright, 1971), though some authors have suggested that chronic copper poisoning may play an important role in some types of cirrhosis in man (Hunt et al., 1963). Blomfield et al. (1971) showed that tap water acting on copper plumbing led to increases in copper levels in haemodialysis units. With our family, the water was particularly acid and the hot water system had a copper storage tank. It would be expected that if the child had chronic copper poisoning his parents and sib, who were the only other people to drink from the same water supply, should also have evidence of chronic copper poisoning; however, their plasma copper levels, serum transaminases, and urinary copper levels both before and after penicillamine were not significantly raised except for the second 24 hours in his mother, and such urine copper levels are consistent with high normal values or values found in heterozygotes of Wilson's disease ( $\mathrm{Tu}$ and Blackwell, 1967).

The extremely high liver copper levels, higher thap those usually found in children dying with Wilson's disease, suggest the possibility of copper poisoning. In fact our child may have been exposed to high copper levels in utero via the maternal circulation, in view of the high urine copper levels found in his mother after penicillamine. This might be expected to be a particularly vulnerable period as physiologically the fetal liver is endowed with a special copper-binding protein. This enables the fetal liver to accumulate a store of copper to tide the newborn infant over the first few months of neonatal life, when the breast milk has insufficient copper for normal development and growth. This 'fetal' protein, neonatal hepatic mitochondrocuprein (Porter, 1966), binds 3 to $5 \%$ of copper compared with $0 \cdot 3 \%$ of copper for 'adult' hepatocuprein. It normally diminishes rapidly, along with the stored copper, in the first 3 months after birth. Our patient was not only likely to have been born with an abnormally high content of copper in the liver, but additionally would have been unable to rid the liver of its overload because of a high dietary intake in his postnatal life.

The final diagnosis in this child must remain uncertain. Three possibilities exist. The first is that this child had Wilson's disease and that he had the singular misfortune to live in an environment where he had been exposed to high levels of copper in his diet and so developed clinical manifestations of this disease at an earlier age than usual. The second possibility is that he died from the effects of chronic copper poisoning, in view of the very high level of copper in his drinking water. The third possibility is that he had an intrauterine or neonatal liver infection and was subsequently exposed to high copper levels.

The raised copper levels in drinking water reported here suggest that all cases of suspected Wilson's disease should have the copper content of their drinking water investigated and in this way the role of excess dietary copper intake in the pathogenesis of liver disease will be more clearly understood.

We thank Drs. Mayman and Mitchell who referred the patient, and Dr. R. D. K. Reye who reported the liver pathology.

\section{REFERENCES}

Blomfield, J., Dixon, S. R., and McCredie, D. A. (1971). Potential hepatotoxicity of copper in recurrent hemodialysis. Archives of Internal Medicine, 128, 555.

Blomfield, J., and MacMahon, R. A. (1969). Micro determination of plasma and erythrocyte copper by atomic absorption spectrophotometry. Fournal of Clinical Pathology, 22, 136.

Chuttani, H. K., Gupta, P. S., Gulati, S., and Gupta, D. N. (1965). Acute copper sulphate poisoning. American fournal of 
Cumings, J. N. (1968). Trace metals in the brain and in Wilson's disease. Fournal of Clinical Pathology, 21, 1.

Danks, D. M., Stevens, B. J., Campbell, P. E., Gillespie, J. M., Walker-Smith, J., Blomfield, J., and Turner, B. (1972). Menkes' kinky-hair syndrome. Lancet, 1, 1100.

Hunt, A. H., Parr, R. M., Taylor, D. M., and Trott, N. G. (1963). Relation between cirrhosis and trace metal content of liver. With special reference to primary biliary cirrhosis and copper. British Medical fournal, 2, 1498.

Nicholas, P. O. (1968). Food-poisoning due to copper in the morning tea. Lancet, $2,40$.

Pearson, J. K. L. (1956). Copper poisoning in sheep following the feeding of a copper-supplemented diet. Veterinary Record, 68, 766.

Porter, H. (1966). The tissue copper proteins: cerebrocuprein, erythrocuprein, hepatocuprein, and neonatal hepatic mitochondrocuprein. In The Biochemistry of Copper, Proceedings of the Symposium on Copper in Biological Systems, New York 1965 , p. 159. Ed. by J. Peisach, P. Aisen, and W. E. Blumberg. Academic Press, New York and London.
Salmon, M. A., and Wright, T. (1971). Chronic copper poisoning presenting as pink disease. Archives of Disease in Childhood, 46, 108.

Scheinberg, I. H., and Sternlieb, I. (1965). Wilson's disease. Annual Review of Medicine, 16, 119.

Todd, J. R., Gracey, J. F., and Thompson, R. H. (1962). Studies on chronic copper poisoning. I. Toxicity of copper sulphate and copper acetate in sheep. British Veterinary fournal, 118, 482.

Tu, J-B., and Blackwell, R. Q. (1967). Studies on levels of penicillamine-induced cupriuresis in heterozygotes of Wilson's disease. Metabolism, 16, 507.

Walshe, J. M. (1967). The physiology of copper in man and its relation to Wilson's disease. Brain, 90, 149.

Walshe, J. M., and Briggs, J. (1962). Caeruloplasmin in liver disease. A diagnostic pitfall. Lancet, 2, 263.

Correspondence to Dr. J. A. Walker-Smith, St. Bartholomew's Hospital, London E.C.1.

The following articles will appear in future issues of this journal:

Absorption of fat and calcium by low birthweight infants from milks containing butterfat and olive oil. D. Barltrop and T. E. Oppé.

Goldenhar's syndrome: oculoauriculo-vertebral dysplasia. D. H. Mellor, J. E. Richardson, and D. M. Douglas.

Growth of suckling rats after treatment with dexamethasone or cortisol: implications for steroid therapy in human infants. S. W. De Souza and B. P. F. Adlard.

Pica with rapid improvement after dietary zinc supplementation. K. M. Hambidge and A. Silverman.

Combined live measles-mumps virus vaccine. R. E. Weibel, V. M. Villarejos, G. Hernández C., J. Stokes, Jr., E. B. Buynak, and M. R. Hilleman.

Congenital adrenal hyperplasia: report of a case with neurological complications. F. Hanefeld, L. Crome, N. E. France, and A. D. M. Jackson.

Exercise as a screening test for growth hormone deficiency in children. K. A. Lacey, A. Hewison, and J. M. Parkin. 